\title{
O MUNDO RURAL E AS ORGANIZAÇÕES DE OPOSIÇÃO SINDICAL LIDERADAS POR MULHERES
}

\author{
Priscila Dantas*
}

\begin{abstract}
RESUMO: Contemplando as atuações e movimentos em torno dos Sindicatos dos Trabalhadores Rurais (STR) das regiões do Seridó e Curimataú paraibanos, este trabalho objetiva contextualizar o leitor no universo sociopolítico onde mulheres adentraram em espaços de poder, resultando nas chamadas Organizações de Oposições Sindicais, direcionadas por mulheres, entre os anos de 1985 a 1995. Insatisfeitas com as precárias condições dadas aos camponeses e sindicalistas, além da exclusão dos direitos assegurados pela sindicalização feminina, as mulheres assumem posicionamentos pioneiros contra o poder masculino, detentor das diretorias dos STRs por longos anos, iniciando articulações pelas regiões afim de criar grupos formadores de oposições a essas chapas. Por meio da figura masculina, ainda muito forte dentro do mundo rural, essas mulheres se inserem nas campanhas eleitorais e a partir delas promovem mudanças no interior desses espaços.

PALAVRAS-CHAVE: Sindicato; Mulheres; Oposições; Movimentos.
\end{abstract}

\section{The rural world and the women-leaded union organizations of trade unions}

SUMMARY: Contemplating the actions and movements around the Rural Workers Unions (STR) in the Seridó and Curimataú regions of Paraíba, this paper aims to contextualize the reader in the sociopolitical universe where women entered spaces of power, resulting in the so-called Union Opposition Organizations, directed by women, between 1985 and 1995. Unhappy with the precarious conditions given to peasants and trade unionists, in addition to the exclusion of the rights guaranteed by women's unionization, women take on pioneering positions in the face of male power, which has held the boards of STRs for many years, initiating articulations by the regions in order to create groups opposing these boards. Through the masculine figure, which is still very strong within the rural world, these women are inserted in the electoral campaigns and from there they promote changes inside these spaces.

KEYWORDS: Syndicate; Women; Oppositions; Movements.

\section{El mundo rural y las organizaciones de oposición sindical lideradas por mujeres}

RESUMEN: Contemplando las actuaciones y movimientos acerca de los Sindicatos de los Trabajadores Rurales (STR) de las regiones del Seridó y Curimataú paraibanos, este trabajo objetiva contextualizar al lector en el universo sociopolítico donde mujeres adentraron en espacios de poder, resultando em las llamadas Organizaciones de Oposiciones Sindicales, dirigidas por mujeres, entre los años 1985 a 1995. Insatisfechos como precarias condiciones dadas años campesinos y sindicalistas, además de la exclusión de los derechos asegurados por la sindicalización femenina, las mujeres asumen posicionamientos pioneros contra el poder masculino, poseedor de las directorios de los STRs por largos años, iniciando articulaciones por las regiones a fin de crear grupos formadores de las oposiciones a dichas planchas. Por medio de la figura masculina, aún muy fuerte dentro del mundo rural, esas mujeres se inserta em las campañas electorales ya partir de ellas promueven transformaciones en el interior de esos espacios.

PALABRAS CLAVE: Sindicato; Mujeres; Oposiciones; Movimientos.

\footnotetext{
* Mestra em História pela Universidade Federal da Paraíba. Atualmente é Secretária de Educação do município de Nova Palmeira-PB. Contato: Rua: Almisa Rosa, 02, Centro, CEP: 58184-000, Nova Palmeira, PB, Brasil. Email: pri_msd@hotmail.com. ORCID: https://orcid.org/0000-0002-0187-8486.
} 


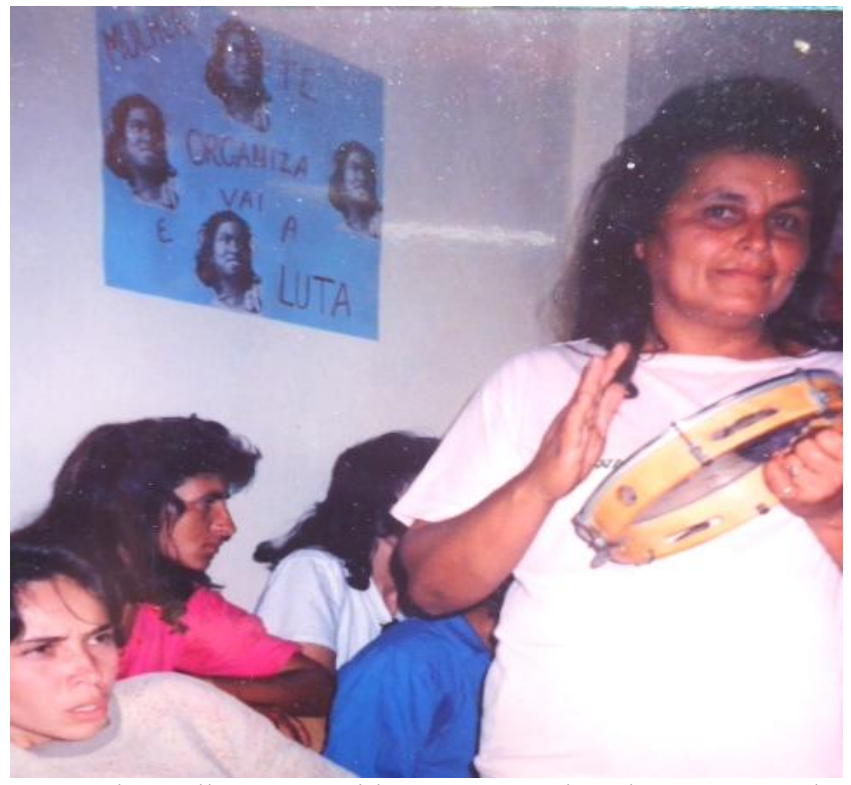

Imagem - Retrato do "Encontro de Mulher", ocorrido no Centro de Educação Popular (Cenep), com o apoio da Escola Estadual de $1^{\circ}$ Grau Antônio Coelho Dantas, na cidade de Nova Palmeira-PB, em 10 de março de 1991 (FONTE: Acervo fotográfico do Cenep).

A fotografia ${ }^{1}$ acima bem poderia representar um mero momento de lazer e de descontração vivenciado por um grupo de mulheres qualquer, em algumas de suas muitas corriqueiras atividades de lazer e/ou datas comemorativas escolares. Mas do que nos fala esse olhar da mulher que toca o seu instrumento? Quem é ela? Quem são elas? Que histórias se entrelaçam nesta imagem?

Se não fosse pelo cartaz ao fundo, no qual aparece o slogan "Mulher, te organiza e vai à luta", talvez essa fotografia não tivesse nenhuma importância para a História, posto que não se trata de grandes líderes feminista no cenário nacional; a fotografia também poderia não ter nenhuma importância para esta aprendiz de historiadora, se não trouxesse à cena um fragmento de outras histórias, que tratam de iniciativas e ações aguerridas de um grupo de mulheres que vivenciaram experiências singulares num pequeno município do interior da Paraíba e que não se conformando com suas precárias condições sociais, de suas famílias e de suas comunidades, se lançaram pelos áridos caminhos da política.

É como um olhar mais curioso e entendendo que esta imagem apenas captura o instante, o fragmento congelado de uma história que ainda está por ser contada, que tento pensar sobre este e outros registros analisados ${ }^{2}$, neste trabalho. Registros que se tornam emblemáticos no sentido de demarcar intenções de "luta", de "organização" e de "ação" por parte das mulheres envolvidas; são registros vistos aqui como reveladores de um enredo oculto, à espera de um olhar em forma de problemática histórica, pronto para ser investigado e 
tornado público, alargando e se agregando a uma historiografia ainda frágil de narrativas peculiares e de sujeitos (in)comuns.

A mulher que toca é a funcionária pública Fátima de Lé (como era conhecida), apenas uma das muitas participantes que fazem parte das atividades comemorativas do Dia da Mulher, apoiados pela ONG Centro de Educação Popular (Cenep), em $1991^{3}$. Era a partir de eventos como estes que o grupo de mulheres estruturado a partir da ONG, estabelecia relações de proximidade com a comunidade. Estrategicamente tratava de questões mais amplas ligadas à condição feminina no município de maneira geral. Desta forma, outra indagação pode ser apontada aqui: como as reivindicações de um pequeno grupo de mulheres acabaram por possibilitar mudanças na estrutura sindical e social da região do Seridó e Curimataú paraibanos?

A historiografia paraibana sobre movimentos sociais que inscrevem as mulheres como protagonistas estão, ainda, permeadas por enredos particulares, análises e discursos individualizados centrados em figuras como Elisabeth Teixera, Margarida Maria Alves, Maria da Penha Silva. Apesar da importância dessas histórias, no sentido de apontar para um enorme avanço na historiografia ${ }^{4}$ acerca da participação feminina no cenário paraibano e nacional, ainda percebe-se uma carência de narrativas comuns, de práticas peculiares e mobilizações de cunho esquerdistas que se estenderam a outros territórios na Paraíba.

Dessa forma, este trabalho apresenta as ações lideradas por mulheres em um espaço interiorano onde a figura masculina era predominante nos espaços públicos, nas organizações sindicais, nos partidos políticos. Dentro de uma estrutura cercada pela força do campo, um grupo de mulheres (rurais e urbanas) surge garantindo a luta pela igualdade de direitos e participação política, como podemos verificar na fala de Nega Lourdes ${ }^{5}$ :

Foi um desfile de 7 de setembro. A gente saiu de última hora, saímos escondidas. Montamos um pelotão no dia 7 e saímos com as panelas vazias, com faixas. Foi na época do Grito dos Excluídos. A gente se escondeu. De última hora saímos com as faixas e batendo panelas vazias dizendo: "Estamos com fome!". Porque o prefeito não dava aumento a ninguém, era um prefeito desastrado na época. Então a gente fez isso.

$O$ Grito dos Excluídos ${ }^{6}$. Enquanto as autoridades na cidade de Nova Palmeira ${ }^{7}$ preparavam-se para as comemorações da semana da pátria, a população foi surpreendida por uma passeata composta por mulheres reivindicando melhorias salariais e maior participação popular nos espaços públicos. A mobilização aconteceu em 7 de setembro de 1995.

Mapeando rapidamente as ações tecidas para reivindicar posicionamentos assumidos pelos dirigentes da cidade, a fala da entrevistada, resquícios de memória, demonstra a 
influência do cenário sociopolítico que vivia o Brasil no final da década de 1980 e início dos anos 1990, quando chegou ao auge às manifestações conhecidas por "O Grito dos Excluídos", que tiveram grande repercussão nesse momento da história. Além disso, percebe-se um determinado grau de unidade entre os grupos se comparado ao contexto os quais as mobilizações foram promovidas, já que se realizava o desfile municipal em comemoração à data de independência do Brasil.

Por meio do uso de panelas e faixas, a ideia de fazer às escondidas e surpreender a população, remete-nos à ideia de um grupo articulado, que já possuía uma maturidade de reivindicação, de luta e mobilização social, além de compartilhar e abraçar ideais coletivos, capazes de enfrentar as autoridades.

Ainda sobre o depoimento, quando a entrevistada cita que a decisão foi tomada de última hora, remete-nos a um determinado cuidado na articulação do movimento, uma vez que se tratava de mulheres se mobilizando para denunciar relações de poder e a situação econômica do município, que tanto excluía boa parte da população, como pagava míseros salários aos trabalhadores que, em geral, passavam anos sem receber aumento, durante um desfile de caráter e tradição nacional, patriótico.

O uso da expressão "Estamos com fome!" nos cartazes e falas proferidas demarcam reivindicações básicas da sociedade, indo desde problemas relacionados à pobreza que assolava a população, pessoas que literalmente passavam fome e sede sem receber nenhuma assistência pública, às questões como aumento salarial, garantia de direitos, investimento em educação, saúde, cultura e infraestrutura. A “fome” citada refere-se à falta de atenção básica do poder público com as mínimas necessidades da população.

Nesse sentido, percebemos, a partir dos documentos e entrevistas coletados, que as mobilizações lideradas por mulheres passaram a se expandir de Nova Palmeira para municípios circunvizinhos, demarcados geográfico e culturalmente por Seridó e Curimataú paraibanos $^{8}$. Verificou-se um forte compartilhamento de insatisfações sociais, no qual grupos, majoritariamente formados por mulheres, organizaram-se para atuar em benefício dos mais necessitados, decorrentes de uma cultura política ${ }^{9}$ que tanto excluía boa parte da população, como mantinha práticas oligarquias e patriarcais.

Sendo assim, este trabalho ${ }^{10}$ consiste em apresentar experiências e lutas de mulheres nas regiões do Seridó e Curimataú paraibanos, durante os anos de 1985 a 1995, visando contextualizar suas práticas e as mudanças que se gestaram ao longo do processo, uma vez 
que deparamos, no final da década de 80 , com movimentos rurais liderados por mulheres e tidos como pioneiros.

Nomes, como os de Nega Lourdes, Dona Mocinha, Marisinha, Tedinha, Cícera, Irmã Conceição, Irmã Consuelo, Rosinha, Aparecida (Cida), são constantes nos depoimentos dados e nos documentos coletados, enquanto mulheres ativas no protagonismo dessas ações. Além de outras professoras, agentes pastorais, agricultoras, funcionárias públicas, estudantes, sindicalistas que dão norte e continuidade às perspectivas de mudança, visando à melhoria social por meio de uma boa educação, saúde, moradia, cultura, infraestrutura e, especialmente, participação política.

Do ponto de vista teórico-metodológico, este trabalho se desenvolveu no campo da Nova História Política em diálogo com a História Cultural. Nesse aspecto, é importante apontar que, de acordo com Falcon (1997), a política é uma dimensão da história que apareceu com a história política tradicional. Centrada no poder, essa categoria da narrativa histórica vem se fazendo sob temas do mundo econômico, jurídico, eclesiástico, administrativo, social. Por isso, o que se pretende com essa nova forma de fazer e pensar a história política é estabelecer diferentes maneiras de construir questões sobre a sociedade e suas diversas esferas de atuação, mecanismos que visualizam as pluralidades do objeto estudado, suas variações e simbologias que mudam de lugar e tempo, abrindo, inclusive, portas para análise de novos personagens, sujeitos sociais que ficaram à margem da história por muito tempo, denominada de "história vista de baixo", ou seja, de pessoas e massas anônimas (BARROS, 2012, p. 26).

Com a abordagem interdisciplinar dessa história política, muitas problemáticas começaram a surgir. Olhares interessados nas instituições sociais e políticas, tais como sindicatos, partidos, igrejas, eleições, começam a serem focos de estudos, ampliando o leque de objetos de pesquisa. Diante disso, novas reflexões, teóricas e metodológicas, começaram a se desenhar. Era preciso construir outros caminhos para compreender a prática social (RÉMOND, 2003). Dessa forma, este trabalho traz a figura feminina como protagonista, um gênero por muito tempo esquecido e omitido pela historiografia até o século XIX.

Nessa perspectiva, a proposta para este artigo consistiu na organização de experiências que tragam tanto o universo das lutas sociais, em especial as do campo, em consonância com o protagonismo das mulheres frente aos desafios que esse tipo de história impõe, buscando entender o papel da educação e da Igreja Católica através da Teologia da Libertação nesse contexto, fatores que permitiram a constituição de espaços propícios às reivindicações e 
engajamento social, além de problematizar como se tornou possível a formação de uma rede de sociabilidades entre mulheres, nas quais se reuniam práticas e ideologias semelhantes. Dessa forma, pretende-se contextualizar o leitor no universo sociopolítico onde mulheres adentraram espaços de poder.

O fio condutor deste estudo parte da análise dos movimentos e experiências do cotidiano, vividos e pensados nas comunidades de base, com grupos de ideologias populares, onde o desejo de melhoria de vida se mesclava às reivindicações sociais, partindo da ideia do direito cidadão e seu reconhecimento por parte do todo (poder público e da própria sociedade civil), pelas experiências vividas e compartilhadas, e não meramente por opressão de uns ou miséria de outros.

\section{Transição para a democracia, luta por cidadania e a emergência de novos debates}

O processo de transição democrática no Brasil, lento e gradual, foi um dos mais singulares da América Latina por ter se dado dentro de uma longa temporalidade. De início, eram os militares os condutores do processo, parecendo ser mais uma reconfiguração do sistema, do que propriamente uma abertura política. Foi a partir das eleições de 1974 que o partido de oposição teve destaque, indicando falta de apoio popular ao regime, bem como se apresentaram divisões internas dentro da instituição militar, além da forte crise econômica que fortalecia a ideia do então presidente Ernesto Geisel em prosseguir com a proposta de abertura política. Fato que não agradou a todos, especialmente aos militares pertencentes da turma dos "linha-dura" da ditadura, demarcando um período de campanhas muito violentas contra a esquerda. Ameaças aos defensores e propagadores dos ideais esquerdistas, a exemplo dos jornais e jornalistas da imprensa alternativa, bem como ataques com bombas a instituições, somada à crescente inflação e desordem econômica, fizeram desse momento um marco histórico para o início real e efetivo da redemocratização.

Esse processo de transição política no Brasil foi bastante longo, caminhou, de acordo com Skidmore (1988), sob violentas e autoritárias manobras políticas, somado ao acelerado aumento inflacionário. As greves continuavam e os grupos de esquerda juntamente com a classe trabalhadora se organizavam para fundar instituições capazes de reunir e defender seus interesses, como foi o caso do Partido dos Trabalhadores e a Central Única dos Trabalhadores, a $\mathrm{CUT}^{11}$.

Nesse período, os grupos de base se constituem como grandes influencias políticas, a exemplo das Comunidades Eclesiais de Base, as CEBs, oriundas das mobilizações populares 
da Igreja Católica, dos Grupos e Associações de Bairros e dos sindicatos. À medida que o setor econômico estava em desaceleração na década de 1980, a classe operária se tornava mais forte e unificada, ressurgindo e operando como agente fundamental nesse processo de abertura política. A mídia alternativa também foi uma grande aliada nesse processo, desenvolvendo o papel de veiculadora de críticas, denuncias e exigências por parte da sociedade pela concretização da liberdade política e democrática.

Nesse período a Paraíba vivenciava uma difícil problemática agrária, o que possibilitou a organização e atuação de sindicatos, fortalecendo as lutas sindicais nos anos seguintes. De acordo com Nunes (2009), a Igreja Católica também teve um papel importante na operação das lutas populares e sindicais no Estado, assim como setores universitários e estudantis, e os movimentos feministas junto com o apoio da Ordem dos Advogados. Mesmo diante da supremacia do poder estatal sobre a sociedade paraibana, algo bastante marcante em sua história política foi à atuação dessas mobilizações sociais e organizações populares que tiveram seus espaços e importância durante o processo de transição no Estado, fortalecendo os sindicatos e instituições sociais.

É importante ressaltar que, de acordo com Kinzo (2001), com o fim do Ato Institucional $n^{\circ} 5$ (AI-5), a aprovação da anistia em 1979 e a formação de novos partidos, rompendo com o até então bipartidarismo nacional, a liberalização continuava, sendo fortalecida com as possíveis eleições de 1982. Políticos exilados voltaram a se candidatar, governantes são eleitos pelo voto popular, mas ainda eram os militares "os cabeças" que comandavam os colégios eleitorais, assumindo a presidência novamente.

É nesse período que toma destaque a campanha das “Diretas Já!” (1983-1984) com considerável apoio popular. Um movimento político democrático favorável à emenda feita pelo deputado Dante de Oliveira em prol do restabelecimento das eleições diretas no Brasil. Comícios e passeatas foram realizados em muitas cidades do país, contando com a participação de milhares de brasileiros, partidos e instituições, que resultaram, mais à frente, em transformações regularizadas pela Constituição Brasileira de 1988 (GOHN, 2008). Nas manifestações havia pessoas tanto do universo popular quanto da elite, estudantes, acadêmicos, professores, trabalhadores domésticos, moradores de bairros, agricultores, sindicalistas, religiosos e demais agentes sociais que compartilhavam dos ideais de mudança e defesa de direitos. Mesmo o projeto de emenda constitucional das eleições diretas para presidente da república não sendo aprovada no Congresso, demonstrando a força que os militares ainda possuíam, as manifestações foram importantes no que se refere à participação 
da sociedade civil no processo de reorganização política do país, demarcando o ressurgimento da sua interferência no cenário político.

De acordo com Stepan (1988), diferente de um Brasil do ano de 1964, tínhamos em 1984, duas décadas depois, um novo cenário. À medida que chegavam ao fim alguns grupos políticos, crescia uma nova geração, nascida entre esses períodos, ansiosa por mudanças significativas na economia, política e sociedade brasileira.

A atuação dos movimentos sindicais no Brasil nesse período, de maneira geral, mobilizou os trabalhadores na luta pela melhoria e asseguramento dos seus benefícios, em que a participação das mulheres, por muitas vezes esquecida ou omitida pela historiografia, tem suas marcas na transformação da sociedade, seja enquanto trabalhadoras, agricultoras, estudantes, sindicalistas, militantes, professoras, seringueiras, operárias, como veremos mais adiante.

O operariado, que vinha de uma caminhada organizada de greves desde fins dos anos 1970, é um dos setores urbanos com grande expansão no momento, mesmo que em partes desconfiasse das instituições políticas, não dando crédito, por exemplo, ao partidarismo. Divisões desse tipo causaram no ano de 1983, por um lado, a fundação da Central Única dos Trabalhadores (CUT), por um grupo, e a formação da Confederação Geral dos Trabalhadores (CGT), fundada em 1986, por outro.

No âmbito do político, o processo foi de intensa democratização, pois a sociedade conquistava cada vez mais espaços de participação e contestação, resultado disso foi à promulgação da Constituição de 1988, na qual, por um lado, havia os grupos detentores do poder querendo assegurar seus poderes, do outro, uma esquerda que teve fundamental participação no processo constituinte, representando um avanço singular da atuação social no poder público e constitucional (KINZO, 2001).

De acordo com Marilena Chauí (2007), o fortalecimento das esquerdas e da própria ideia de América Latina é proveniente desse período ditatorial pela qual passaram os países dessa parte do continente. Ditaduras que aconteceram simultaneamente e que entrelaçaram as ideologias esquerdistas entre os países vizinhos, assegurando o intercâmbio, a troca de interesses e práticas políticas semelhantes não só entre os políticos, mas também, e especialmente, entre os intelectuais e movimentos sociais, resultando em pontes fundamentais de articulação e redes de solidariedade frente ao autoritarismo que tinha por meta proteger o Estado do comunismo. 
Bandeiras carregadas por esses grupos, com o fim da discriminação racial e da desigualdade entre homens e mulheres, passam, desde o período de abertura política no Brasil, a ganhar espaço no debate constitucional, à medida que outras pautas de luta, como a reforma agrária, que continuava estancada nos armários e discussões institucionais. Entretanto, e vale reforçar, a configuração de um cenário de crescimentos das esquerdas e propagação de suas ideias, em que as reivindicações sociais, a participação popular, o ressurgimento dos movimentos sindicais e trabalhistas, foram fundamentais para o processo de reconstrução, ou melhor, construção da democracia brasileira.

De acordo com Carvalho (2015), para conversar sobre processo de democratização no Brasil é importante que reflitamos sobre uma palavra que nesse período esteve muito em voga: cidadania, expressão que caiu, "literalmente, na boca do povo", "virou gente" (p. 13), tanto que a Constituição de 1988 ficou conhecida por "Constituição Cidadã”, o que, segundo o autor, trouxe falsas ilusões de "felicidade nacional".

Sem negar as conquistas de todo esse processo, como o direito de eleger prefeitos, governadores, presidentes, de a população ter voz e participação nos espaços públicos, sem negar a livre expressão, os movimentos sociais, o autor sinaliza fracassos em outros aspectos dessa idealização cidadã quando os altos níveis de analfabetismo continuam, a exemplo da violência urbana e do desemprego cada vez mais alarmante, má gestão e investimento em educação, saúde e saneamento, agravando a já forte desigualdade social.

Pensar a cidadania nesse momento no Brasil é compreender que ao passo que veio a liberdade, as mazelas da sociedade continuaram, não houve uma resolutividade dos problemas básicos ou uma preocupação dos poderes públicos em resolver e cuidar dessas deficiências. Nesse caso, temos cidadãos pela metade, ou seja, apenas com alguns direitos reconhecidos, consumindo do máximo, apenas o mínimo, já que:

\begin{abstract}
Direitos civis são os direitos fundamentais à vida, à liberdade, à propriedade, à igualdade perante a lei. Eles se desdobram na garantia de ir e vir, de escolher o trabalho, de manifestar o pensamento, de organizar-se, de ter respeitada a inviolabilidade do lar e da correspondência, de não ser preso a não ser pela autoridade competente e de acordo com as leis, de não ser condenado sem processo legal regular. São direitos cuja garantia se baseia na existência de uma justiça independente, eficiente, barata e acessível a todos. São eles que garantem as relações civilizadas entre as pessoas e a própria existência da sociedade civil surgida com o desenvolvimento do capitalismo. Sua pedra de toque é a liberdade individual (CARVALO, 2015, p. 15).
\end{abstract}

Ser cidadão e ter direitos é algo condicionado pela condição social, pelas relações de poder e pela cultura. Sob a máscara de cidadania plena e felicidade nacional, a sociedade 
brasileira construiu sua democracia sob uma estrutura vulnerável, por exemplo, ao capital internacional que ditava como a economia deveria ser conduzida.

A garantia de uma boa educação, saúde, trabalho, salário, aposentadoria é dada pelos direitos sociais que só podem ser assegurados por uma administração sensível e capacitada para o desenvolvimento da gestão e execução das leis tal como na constituição. De acordo com Carvalho (2015), uma das maiores dificuldades em se estabelecer uma cidadania digna é a falta de qualificação educacional, na qual eduque a sociedade para o que lhe é de direito e dever, algo que não acontece historicamente no Brasil e quando acontece, em geral, é pela chamada educação popular, que tem por preocupação central formar pessoas críticas e conhecedoras da sua realidade social e seu lugar por direito dentro dela.

A construção da cidadania tem muito a ver com a noção de Estado-Nação, uma vez que ambos estão inseridos dentro de uma perspectiva nacional, se sentindo parte e produto dela. Uma pessoa passa a se sentir cidadã à medida que se identifica com a língua, com as tradições e costumes, aspectos que caracterizam a identidade nacional. Dessa forma, "a maneira como se formaram os Estados-Nação condicionam assim a construção da cidadania" (CARVALHO, 2015, p. 18).

Esse processo durante a redemocratização do Brasil ficou marcado, especialmente, pelo crescente ressurgimento da participação popular, que antes havia sido reduzida drasticamente. A inovação dos movimentos sindicais com o surgimento do Partido dos Trabalhadores, da CUT, de instituições que unificaram suas bandeiras de luta, como do próprio aparecimento público dos sindicatos rurais, necessitava de crescer, ampliar os horizontes, aparecer em termos de assistência e efetividade, algo que ficou, em partes, a cargo da Igreja Católica por meio do trabalho desenvolvido pelas Comissões Pastorais da Terra, semeando territórios de debate em torno do ativismo e da participação dessas instituições na política de maneira geral, na busca por melhorias assistenciais ao trabalho no campo.

Ainda de acordo com Carvalho (2015), a inovação dos movimentos sociais também tem papel importante nesse processo de afirmação cidadã, pois à medida que se tem o fim das guerrilhas formadas nos idos de 1960, surgem novos sujeitos sociais, novas instituições que vão agir efetivamente junto à sociedade, aos movimentos de base, às associações de bairro, como é o caso da Igreja Católica adepta da Teologia da Libertação, tornando-se "um baluarte da luta contra a ditadura militar" (p. 187).

O papel desenvolvido pelas CEBs, surgidas em 1975, teve como objetivo trabalhar, dentro do universo rural, com os jovens através dos movimentos estudantis, com grupos 
marginalizados socialmente, partindo da conscientização política de uma fé ligada à ação, à crítica, à prática por melhorias sociais, uma luta pelo bem comum, o bem estar das massas por anos oprimidas e excluídas do processo político.

Criou-se uma rede de solidariedades entre as bandeiras cidadãs e de cunho esquerdistas, unindo os vários grupos, partidos, intelectuais e instituições em prol de discutir e tratar das necessidades do cotidiano agravadas pela desassistência do regime. O retorno da democracia no Brasil não significou dizer que trouxe resolução para os problemas sociais, políticos e econômicos. O desemprego e a desigualdade ainda estavam atingindo drasticamente os setores mais pobres, bem como a má educação, saúde e infraestrutura. $\mathrm{O}$ final dos anos de 1980 termina sob uma cidadania construída com sombras de esperança e ondas de incerteza $^{12}$

A crise de civilização que passava o mundo, com pessoas desacreditadas e fragilizadas pela miséria e pobreza, permitiu a geração de campanhas geradoras de esperança, criando sentido para viver e de estar no mundo. Teólogos da Igreja Católica, preocupados em dar conta dessas debilidades sociais, buscaram doutrinas que faziam da fé não só um pilar espiritual, mas uma crença engajada, solidária e combativa (CATÃO, 1986).

Dessa forma, surge a Teologia da Libertação como um questionamento feito por líderes eclesiásticos preocupados em dar sentido à vida, em cuidar da vida, especialmente daqueles mais pobres e oprimidas, desesperançosos de mundo melhor. A busca pela emancipação dos oprimidos e explorados surge da necessidade de acabar com as práticas opressoras, excludentes, dominantes e exploratórias que acometiam as camadas mais pobres da sociedade. Dessa forma, a Teologia da Libertação tinha por objetivo germinar nos oprimidos uma consciência sobre sua condição social, fazendo com que eles lutassem pela própria emancipação. Libertar esses indivíduos da marginalidade em benefício de uma transformação social tornou-se ponto de partida dos adeptos dessa teologia.

A reorganização política do país, desde meados da década de 1980, todo o contexto de mudança e transformação social, acabou por influenciar em contextos menores, a exemplo do que aconteceu nas regiões do Seridó e Curimataú paraibanos, onde um grupo de mulheres se lançou pioneiramente nas campanhas de oposição sindical às antigas chapas que dominavam os sindicatos rurais, como veremos a seguir.

\section{A atuação de mulheres no espaço sociopolítico na Paraíba}


A Paraíba dos anos de 1990 carregava em sua história política as marcas do clientelismo e do coronelismo, uma vez que seu caráter agrícola ainda dominava a economia e a concentração de pessoas no campo era bastante considerável, embora o processo de migração para a zona urbana fosse visível. Também se vivia um processo emancipacionista. Muitas cidades paraibanas surgiram na década de $1990^{13}$, influenciadas pelo que se visualiza no Brasil diante da conjuntura sociopolítica pós-redemocratização e o avanço dos grandes centros urbanos.

A descentralização de recursos viabilizou para muitos cidadãos paraibanos o acesso ao poder público e, a partir dessa acessibilidade, atender às necessidades sociais, tais como saúde, educação, moradia, pavimentação e transporte em territórios ainda distantes dessa realidade. Porém, mesmo as cidades já existentes na Paraíba, especialmente as chamadas "cidades do interior", a carência e fragilidade das estruturas sociais tornavam suas populações extremamente pobres, famintas e analfabetas.

Essa sociedade estava intimamente ligada ao contexto nacional, marcado por uma grave crise econômica na década de 1980 e pela implantação, a partir dos anos de 1990, de políticas e reformas neoliberais que atingiam todas as estruturas normatizadoras da sociedade, avançando-se, inclusive, de forma direta contra os movimentos sociais. Além disso, localmente passava-se por uma grave e prolongada seca. A agricultura familiar, afetada pelo processo de modernização do setor agrário desde a ditadura, tem sua situação agravada pelo capital industrial subordinador da agricultura, sendo o agronegócio o grande beneficiário desse processo.

Para além da seca e da pobreza, diferentes motivos levaram à organização de lutas na Paraíba. Entre as décadas de 1950 e 1960, movimentos sindicais, urbanos e rurais, foram constantes, a exemplo da luta operária na cidade de Rio Tinto ${ }^{14}$, que se acentuou entre os anos de 1959 e 1964, e os movimentos sindicais rurais no Brejo, que resultaram nas chamadas Ligas Camponesas, organizadas por toda Zona da Mata paraibana ${ }^{15}$. Viam-se emergir nessas regiões pessoas de ação, de luta, sendo muitas delas mulheres engajadas à frente dos movimentos.

O papel dessas mulheres influenciou na dinâmica social no restante do Estado. Os movimentos que se formaram entre as décadas de 1980 e 1990 nas regiões do Seridó e Curimataú paraibanos, onde mulheres desempenharam papéis pioneiros, são resultados de trajetórias e experiências que perpassaram os limites locais, mobilizando outros sujeitos e outras lutas. 
Esses foram engajamentos sociais que deixaram marcas não só nas mudanças em sociedade, mas também nas artes, nas religiões, na cultura, na educação, construindo uma cultura política própria daquele espaço. Mulheres que em sua maioria buscavam, através da expressão artística, compartilhar desejos, insatisfações, sentimentos que afligiam a sociedade naquela época. Mil formas de fazer e saber ${ }^{16}$ que descrevem os tipos de atuação em sociedade:

\author{
Vamos irmãs de luta, \\ Trabalhar com dignidade \\ E neste mundo sofrido, \\ Construir fraternidade \\ E trabalhando unidas \\ Ter um mundo de igualdade. \\ (Luisa Marques dos Santos, 1991)
}

Esses foram versos escritos pela agricultora, professora e escritora Luisa Marques, conhecida como Dona Mocinha, para o Encontro de Mulher ${ }^{17}$, que ocorreu na cidade de Nova Palmeira, no dia 10 de março de 1991. O que se nota é um chamado para a luta social, uma convocação para o enfrentamento das carências de um povo sofrido, mergulhado em desigualdades, desemprego, fome, sede, falta de assistência à saúde e educação.

A produção artística, especialmente as que envolviam escritas, era comum dentro das manifestações sociais, e durante as décadas de 1980 e 1990 demarcaram uma característica importante da atuação feminina seridoense e curimatenha. Cartas, versos, rimas, músicas e poemas, eram instrumentos constantes, ferramentas para a conscientização e organização popular.

O cenário social dos anos 1990 é resultado de um processo de desgaste político e econômico vivido após a ditadura, seguido pelo processo de redemocratização do país, marcados por baixos salários, desemprego e péssima qualidade de vida de maneira geral, fatores que fizeram com que diferentes grupos passassem a atuar em sociedade buscando melhorias.

No Seridó e Curimataú paraibanos, durante as décadas de 1970 e 1980, são os grupos ligados à Igreja Católica, organizados, em sua maioria, de acordo com a documentação pesquisada $^{18}$, por mães, donas de casa, agricultores, estudantes, professoras, que dão norte à organização de uma mentalidade voltada para a ação popular, em vista de um cenário marcado por líderes políticos indiferentes às problemáticas. Havia os Clubes de Mães, para ensinar a educar e cuidar dos filhos, os Clubes de Jovens, para formar uma consciência crítica, política e cidadã, além da formação religiosa e moral. 
Por isso, põe-se como fundamental a importância da formação crítica advinda com a Teologia da Libertação, através de grupos de animadores, clubes de mães, mulheres e jovens, CEBs e de outros espaços que também germinavam ideais de luta, de consciência cidadã. Com isso, verificamos que a maciça participação feminina dentro do território religioso tem impacto direto na atuação social ser direcionada por mulheres nessas regiões. O dever de rezar, culturalmente atrelado ao mundo feminino, permitiu a formação de grupos de mulheres não atrelados apenas ao mundo do privado, do lar, mas, também, de pessoas capazes de agir e enfrentar poderes locais e lutar por melhorias e igualdade social.

\section{Os movimentos no campo e a formação de oposições sindicais}

Ele [presidente do Sindicato] não fazia carteira pra mulheres. (...) Aí quando a gente viu a situação foi aparecendo a história que mulher ia se aposentar, e ele dizia: "Não, mulher não se aposenta não, quem vai se aposentar é o homem." Aí eu sempre saía pra reuniões mais comadre Tedinha, mais Nega Lourdes pra Barra de Santa Rosa, Cubati. Quando havia eleição de sindicato eu ia mais elas. E lá eu comecei a ver que as mulheres tinham direito de se sindicalizar. ${ }^{19}$

A fala de dona Mocinha, moradora do sítio Porteiras, faz referência ao enfrentamento com o presidente do STR da cidade de Nova Palmeira-PB, no ano de 1989, e é bastante significativa para nós, porque demarca um ponto importante nas lutas sociais nessas regiões: mulheres insatisfeitas com os lugares que ocupam na sociedade. Os grupos de oposição sindical surgem a partir das lutas travadas por mulheres em busca da sindicalização, e tem seu início, de acordo com a documentação pesquisada, na cidade referida, Nova Palmeira, quando elas participavam dos grupos religiosos e nestes havia uma discussão em torno dos direitos dos trabalhadores, em especial, dos agricultores.

Ainda no depoimento, ela cita os nomes de Tedinha e Nega Lourdes, corriqueiros nas falas dos entrevistados enquanto líderes das mobilizações sociais, as quais estavam sempre à frente dos grupos pastorais e educativos. Juntas com outras mulheres engajadas saiam em busca de informações, do conhecimento necessário para poder enfrentar a autoridade sindical. Para isso, reuniam-se com mulheres agricultoras insatisfeitas com as condições trabalhistas, dando início a um processo que resultou em uma organizada rede de mobilizações civis nas regiões em prol dos direitos da mulher, especialmente, da mulher do campo.

Além da luta pela sindicalização feminina, os trabalhadores rurais insatisfeitos com as administrações dos STRs, unidos aos grupos de mulheres, formaram chapas de oposição em várias cidades para as eleições sindicais, visto que a maioria dos presidentes estava no posto 
desde a fundação do sindicato, na maioria das vezes, sem haver pessoas e articulações que fizessem oposição.

Ainda na fala de Dona Mocinha há referência à firme posição do presidente sobre a participação feminina na instituição, demonstrando o quanto os STRs, especificamente este, estavam marcados por uma cultura machista e patriarcal, em que só quem tinha direito eram os homens e que por isso só eles tinham acesso aos benefícios e à mínima participação política.

\begin{abstract}
Aí fomos para Cuité. O caba de Cuité, Expedito, que era o presidente do Sindicato de Cuité, era uma pessoa muito esclarecida sobre o sindicato, sabe?! Lá ele deu muita explicação à gente. (...) Aí ele disse: "A senhora arrume um bando de mulher e entre à força que é seu direito". Aí no outro dia, quando eu cheguei em casa, não soube fazer nada. Eu disse a José [esposo]: "Vou lá no mundo atrás de mulher pra nós”. Aí me mandei no meio do mundo. Lá na Espera, que era um vizinho. Lá pro Tamanduá. Aí saía de noite mais José, nós ia fazer reunião lá no Tamanduá pra arrumar gente pra o sindicato. Eu sei que com muita dificuldade eu arrumei 15 mulheres. Aí amanheceu o dia de segunda-feira, eu digo: "nós hoje vamos ao sindicato". ${ }^{20}$
\end{abstract}

No depoimento da agricultora, fica clara a não conformidade por parte das mulheres com as condições impostas pelo presidente, indo buscar nas cidades vizinhas informações e conhecimentos necessários para autorizar suas exigências. Além disso, é importante frisar que essas mulheres não só queriam participar da vida sindical, mas desejava algo em troca, a aposentadoria.

Quando ela diz "Aí no outro dia, quando eu cheguei em casa, não soube fazer nada", percebe-se que, encarar lutas como essa, mexiam não só com o cotidiano dessas mulheres, mas também com a esfera psíquica, no emocional, demonstrado a partir da preocupação e receio sobre o que estava enfrentando. O cenário marcado pelo poder masculino, onde nenhuma mulher havia adentrado ou questionado, acarretou possíveis sentimentos de insegurança, mas sem desistir, unia-se com suas companheiras, formando um grupo de mulheres do campo para ir até o STR e exigir participação.

A penetração de mulheres no mundo das lutas sociais, na busca por seus direitos dentro de uma instituição ou espaço público, perpassa pelo debate sobre cidadania, já que entendemos que a conceituação desse fenômeno social no Brasil vem sendo construído a pequenos passos, especialmente a partir do processo de reajuste democrático no país pósditadura, em 1985. A palavra cidadania virou moda e todos queriam propagá-la, ingenuamente, pois ao longo desse processo, voto, conquistas sociais, liberdade de 
pensamento, "não garantem a existência de governos atentos aos problemas básicos da população" (CARVALHO, 2015, p.14), seja ela do campo ou da cidade.

Ainda sobre a fala de Dona Mocinha, podemos afirmar que é emblemática porque ela descreve sobre suas visitas às comunidades chamando as mulheres para juntas exigirem participação, saindo à noite com seu esposo para informar as agricultoras de que elas também tinham direitos aos benefícios sindicais e das necessidades de haver uma mudança de gestão no sindicato. Indo de casa em casa, Dona Mocinha reuniu 15 mulheres, que apoiaram os encontros e passavam as informações aprendidas aos seus pais, tios, sobrinhos, primos e amigos de comunidade, gerando uma circularidade de saberes e conhecimentos importantes na formação de uma mentalidade propícia ao engajamento social no campo.

É importante ressaltar a presença do homem trabalhador que, mesmo ainda permeado por práticas e culturas machistas, embarcou nessa luta, a exemplo do esposo de Dona Mocinha, seu José, que, então sujeito coberto por certo poder na instituição, foi uma força importante para o movimento, já que tinha vez e voz dentro do sindicato, então muitas vezes eram figuras como essa que falavam por elas. Enquanto sindicalizados munidos de direitos, os homens, em sua maioria esposos das agricultoras que embarcaram na luta, colocavam-se como mediadores da fala feminina, dando vez às exigências, aos direitos e deveres de suas companheiras nos encontros do STR.

Não só pelo interesse em que suas esposas tivessem seus direitos garantidos enquanto trabalhadoras, os homens, em sua maioria, levantavam as bandeiras de suas mulheres pelo fato de que a família, no geral, se beneficiaria, tendo em vista a baixa renda e qualidade de vida. $\mathrm{O}$ investimento e assistência do sindicato chegaria em dobro e isso era bom para o rendimento do trabalho familiar.

É válido ressaltar que o homem falar pela mulher durante os encontros e reuniões não significava tirar a autonomia feminina à frente de suas lutas, mas como um veículo para registrar suas queixas e fazê-las serem ouvidas pelas autoridades, afinal, muitos dos companheiros não assumiam suas lutas, apenas apoiavam a causa. Fazer-se ouvir pelos homens era uma forma de driblar a desatenção que os dirigentes tinham com relação ao papel da mulher dentro da instituição, uma exclusão não declarada, mas exercida, já que no censo comum sindicado era um espaço "para homens".

Os Sindicatos Rurais são instituições criadas durante a década de 1950 com bastantes dificuldades. Apesar de se constituírem atrelados ao poder do Estado, eram instituições combativas, mesmo enfrentando as dificuldades para se estabelecerem: 
[...] a legislação trabalhista fora feita para os trabalhadores urbanos, não considerando a especificidade do trabalho no campo, além do que quase não existiam Juntas de Conciliação e Julgamento em cidades do interior, o que seria necessário para que a lei fosse aplicada. O Código Civil, utilizado para o trabalho das Ligas, permitia a organização autônoma dos camponeses, mas não a formação de sindicatos rurais. Além disso, havia grande resistência, por parte dos proprietários rurais, em aceitarem qualquer tipo de organização vinda dos trabalhadores (ABREU E LIMA, 2012, p 50).

Dessa forma, os presidentes dos sindicatos eram os "amigos" dos prefeitos, vereadores, secretários, tornando-se uma instituição conciliadora entre os desejos estatais e os direitos dos agricultores, apaziguando conflitos e desentendimentos que por vezes se formavam entre governo e classe trabalhadora.

É importante salientar que o trato aqui dado sobre a cultura machista é aquele que se enquadra em um sistema de "representação simbólicas, que mistifica as relações de exploração, de dominação, de sujeição entre homem e mulher” (DRUMONT, 1980, p.81), e não concentrado em um conceito único, mas variante a partir das identidades que se constroem sob o gênero feminino e masculino, e das múltiplas manifestações às quais os comportamentos humanos estão sujeitos, no qual o papel de liderança é desempenhado pelo homem e a partir disso moldam modelos culturais de ideologias e relacionamentos distintos e desiguais concebidos, inclusive pelas mulheres, como certos e ideais para o bom caminhar da sociedade.

Entretanto, apesar dessa predominância cultural do homem na deliberação e liderança de lugares e instituições de poder, a exemplo dos sindicatos, houve brechas que permitiram lideranças femininas ascendessem nesses espaços e deixassem suas marcas no trabalho e nos processos de transformação.

$\mathrm{Na}$ Paraíba, por exemplo, tivemos exemplos de sindicalistas atuantes como Elizabeth Teixeira, a partir das Ligas Camponesas, Margarida Maria Alves ${ }^{21}$ e Maria da Penha Nascimento Silva, em Alagoa Grande, além de outras tantas mulheres que percorreram caminhos de luta e enfretamento no campo até a segunda metade dos anos de 1970 e nos idos de 1980 e que por vezes foram esquecidas pela história oficial ${ }^{22}$.

Em meados dos anos de 1980, quando o Brasil passava pelo processo de redemocratização, em que as instituições desempenhavam um papel importante na reorganização do espaço social, chegam às regiões do Seridó e Curimataú paraibanos, a partir dos Encontros Zonais ${ }^{23}$, as chamadas "Comunidades de Formação", redes organizadas pela sociedade civil para a divulgação sobre os direitos e deveres do trabalhador rural. Um 
movimento que teve apoio especialmente da Igreja Católica, ligada na época aos projetos e atividades sociais de maneira geral, dando ênfase aos problemas do campo.

O chamado novo sindicalismo surge no Brasil por volta da década de 1970, sendo considerado a terceira fase dos movimentos sindicais no país. Ele retoma depois de um período de desgaste durante a ditadura civil-militar, ganhando fôlego em meados da referida década. Em agosto de 1983, os trabalhadores e sindicalistas criam a Central Única dos Trabalhadores (CUT), a maior e mais importante central de atendimento às necessidades sindicais, a qual se fixou por todo país, inclusive na Paraíba, em 1984 (NUNES, 1998/1999).

Ainda de acordo com Nunes (1998/1999), na Paraíba, as oposições sindicais já aconteciam desde a década de 1970 com o apoio da Igreja Católica e entidades que se formaram até a década de 1980. Quando a CUT é fundada neste Estado, as articulações entre movimentos populares e sindicais se tornam mais ativas, influenciando diretamente nas atuações sociais dos municípios, como percebeu na documentação analisada.

$\mathrm{O}$ arquivo pessoal de dona Mocinha, cadernos de rascunhos, como ela costuma chamar, é um exemplo disso, pois se coloca como fonte importante para esta pesquisa, uma vez que, no que se refere ao movimento sindical dessa época, os documentos são quase inexistentes. Nesse acervo, encontramos produções artísticas como resumos em forma de músicas ou poemas dos encontros em que ela participava, das cidades que visitava em busca de reuniões, das pessoas que conheceu nesse processo. Documentos produzidos por ela, agricultora e militante sindical, por isso tão peculiar para nós.

Em meio aos cadernos de dona Mocinha, já amarelados pela ação o tempo, nos deparamos com resumos que iam desde sua atuação como professora e agente pastoral, aos Encontros de Pastorais Rurais que aconteciam nas cidades vizinhas. Por meio da Igreja Católica, atuante frente às necessidades sociais mais básicas, as cidades circunvizinhas dialogavam, trocavam ideias, compartilhavam necessidades e carências.

Nos cadernos analisados, o primeiro evento que dona Mocinha faz referência é o Encontro da Pastoral Rural que aconteceu na cidade de Picuí, em 14 de junho de 1986. De acordo com a fonte, as discussões estavam em torno do que seria a Pastoral Rural e sua importância para a vida do homem do campo, sinalizando serem os primeiros passos para a formação dos Encontros da Pastoral Rural na região. Ainda nesse documento, ela procura fazer uma avaliação sobre o evento, enfatizando os pontos positivos e sua influência na formação de um pensamento crítico e coletivo por parte dos agricultores: "Foi uma alerta para nós trabalhadores. Participação de todos. Houve experiência e troca de ideias. Mais 
entrosamento com os grupos.". Em seguida, ela cita os negativos: "Falta dos membros. Atraso de alguns membros. Pouco tempo.”. (Acervo particular de dona Mocinha).

Os Encontros Zonais contavam diretamente com a participação e apoio dos padres das regiões. O Encontro Zonal do Nordeste, ao qual dona Mocinha também faz referência em seus escritos, ocorreu em Nova Palmeira no dia 16 de junho de 1986, contando com a presença do Pe. Donato Rizzi. Nesse registro, ela fala sobre ser a principal preocupação do evento a organização mútua de todos os trabalhadores na luta por exigências nas mudanças de relações e condições de trabalho dos associados aos STR, ressaltando a importância do estabelecimento de redes que envolviam as cidades vizinhas, pois só juntas poderiam promover mudanças significativas na vida das pessoas. Entre as cidades envolvidas, estavam Juazeirinho, Nova Floresta, Frei Martinho, Pedra Lavrada, Cubati, Picuí, Nova Palmeira, todas ligadas pelos padres e paróquias em diálogo.

De acordo com os relatos, aconteceu em 10 de setembro de 1986 o Encontro Zonal do Curimataú, em Picuí, objetivando formar grupos para organizar as próximas reuniões e representar os interesses e decisões de suas respectivas paróquias. O próximo encontro estava marcado para 5 de novembro do mesmo ano, na cidade de Cuité. Em seus registros, dona Mocinha relata sobre encontros ainda ocorridos durante o ano de 1986, como o Encontro de Jovens que aconteceu entre os dias 4 e 5 de outubro de 1986, no município de Lagoa SecaPB.

Nesse sentido, é importante perceber a preocupação em sistematizar o pensamento das trabalhadoras e trabalhadores rurais, no sentido de informá-los e conscientizá-los de que, enquanto sujeitos ativos e cidadãos de direitos, precisavam participar ativamente das atividades dos sindicatos, bem como exigir melhorias nas condições de trabalho. Havia uma mobilização em prol de dar ao sujeito do campo conhecimento suficiente para que o mesmo não fosse lesado em seu espaço dentro dessas instituições, já que por traz dos seus dirigentes havia o poder e controle do Estado, a todo o momento tentando inibir reações vindas de seus filiados.

O papel da Igreja Católica nesse momento é fundamental por proporcionar ao encontro várias experiências sociais, a partir dos grupos, encontros e das pastorais, dando amplitude às carências e fragilidades compartilhadas não só por um ou dois grupos, mas por vários que ali estavam estabelecidos. Cidades que, por meio do trabalho religioso, passaram a dialogar e criar redes de mobilizações sociais, fortalecendo as lutas e o engajamento político. 
A partir do acervo documental do Centro de Educação Popular, encontramos fontes que citam outros eventos acontecidos no ano seguinte, 1987, a exemplo da Assembleia MiniZonal do Curimataú, em 9 de junho, na cidade de Soledade, na qual se faziam presentes representantes de várias cidades, como Juazeirinho, Nova Palmeira, Soledade e Pedra Lavrada. De acordo com as análises feitas do registro, é a partir desse evento que percebe-se a formação de um movimento em torno da ideia de promover reais oposições sindicais nos STRs nas regiões. Entre as cidades envolvidas diretamente, registradas na documentação, estavam Nova Palmeira, Picuí, Cubati, Nova Floresta e Soledade.

Embora caracterizados como encontros religiosos, o trabalho de conscientização sindical e política que vinha sendo realizado pelas pastorais desde o ano anterior, 1986, propiciou a formação de uma mentalidade tendente a buscar melhorias em seus lugares de vivência, demarcando caminhos possíveis de transformação social. De acordo com a documentação e depoimentos analisados, a cidade de Nova Palmeira assume um papel de destaque nessas mobilizações, por participar ativamente dos encontros e em sua grande parte promovê-los. O que fica explícito no $1^{o}$ Encontro de Trabalhadores Rurais sobre Sindicalismo, ocorrido em 5 de julho de 1987, na referida cidade. O relatório em forma de versos, o que era corriqueiro e peculiar na escrita das mulheres nesse período, deixa explícita a necessidade de uma organização maior entre os grupos interessados. O que se percebe é uma convocação constante para fortalecimento de alianças e a amplitude da participação coletiva.

A ideia de organizar o trabalhador, chamá-lo para luta, engajá-lo em grupos de articulação, é constante nos relatórios e resumos de eventos. Dessa forma, percebe-se a existência de uma conscientização no sentido de ampliar as mobilizações por meio da ação coletiva, fundamental para o sucesso de suas propostas.

O papel da mulher nesse cenário foi algo diferencial, uma vez que ficava a cargo dela não só o papel de agir socialmente, mas de documentar, registrar, oficializar os encontros e acontecimentos. Grande parte dos documentos analisados até aqui são, em sua maioria, redigidos por elas e isso fica explícito nas cartas, músicas e poemas com autorias, nos relatórios e resumo assinados e datados, nos registros fotográficos, nas atas e diretorias. À frente dos grupos pastorais, das escolas, dos grupos de oposição sindical, as mulheres assumiram também o papel de deixar caminhos e lugares de memórias.

O movimento sindical no Brejo paraibano, entre os anos de 1960 e 1970, onde a cidade de Alagoa Grande teve grande destaque, inclusive por haver mulheres à frente das 
mobilizações, esteve presente nas expressões e memórias dos trabalhadores e trabalhadoras rurais das regiões do Seridó e Curimataú. A figura de Maria da Penha, forte militante rural na referida cidade, foi tomada como fonte de inspiração e força para as agricultoras e mulheres envolvidas na luta. Nos depoimentos, bem como em escritas, a exemplo de Eliete, elas relatam a importância da presença de figuras como Penha na sistematização do pensamento coletivo, interferindo positivamente na adesão e no engajamento cada vez mais efetivo de mulheres às articulações.

O papel feminino delimita, não só pelo engajamento direto em um campo marcado por líderes machistas e patriarcais, mas também pelas suas expressões artísticas, seus olhares sensíveis às causas do campo, uma característica peculiar das expressões artísticas dessa época e desse movimento. Mulheres que, por meio de suas falas e escritas populares, invadiam o pensamento social com o intuito de transformar uma cultura de medo e acomodação em força para enfrentar situações de miséria e precariedade dos direitos cidadãos. Estratégias $^{24}$ desenvolvidas para que suas mensagens em forma de versos fossem mais facilmente assimiladas pela população.

A organização de encontros constantes também se coloca como uma forma estratégica de divulgar o trabalho, ampliar as discussões e assim conquistar novos participantes. No acervo documental do Centro de Educação Popular (Cenep), é constante a documentação sobre eventos e reuniões realizados entre as décadas de 1980 e 1990 nas regiões, seja por relatórios, seja por atas, por fotografias, ou peças teatrais.

Ainda tomada como foco de articulações e encontros, a cidade de Nova Palmeira realizou no dia 11 de outubro de 1987 o Encontro de Trabalhadores Rurais: Educação Popular, cuja temática de discussão circulava em torno dos "Direitos e Deveres dos Trabalhadores". Mais um evento em que o termo cidadania direcionava os debates e adentrava na mentalidade popular, ainda carente de uma consciência cidadã.

Nesses eventos, eles também discutiam os caminhos que seriam tomados pelas trabalhadoras e trabalhadores rurais frente aos STRs. Nesse encontro, em específico, ficou a cargo do membro da Equipe de Educação Política do Regional Nordeste II e do Serviço de Assistência Rural (SAR) do Rio Grande do Norte, chamado de Joscelito. O que demonstra seguir o movimento por caminhos solidamente construídos, com as informações sendo repassadas não apenas por sindicalistas, mas pessoas institucionalizadas, embasadas não por mera troca de informações, mas sobrecarregadas de leis, de regimentos e estatutos. 
Segundo o relatório desse evento, os debates se cercaram em torno de temas como o capitalismo, partidos políticos, com ênfase nos de esquerda enquanto apoios institucionais importantes na luta social e agrária. O Partido dos Trabalhadores era tema constante, por surgir enquanto ferramenta de base institucional para apoiar as causas trabalhistas.

Também encontramos no acervo documental do Cenep uma cartilha escrita em abril de 1988, intitulada "História e luta de um povo em busca de sua libertação". No documento, estão registradas orientações de encontros sequenciais, em forma de manual, para serem realizados debates com os trabalhadores. Nessa cartilha também demarca a participação da religião por meio da leitura de salmos e evangelhos durante os encontros.

No ano de 1989, formou-se no município de Nova Palmeira um movimento de oposição sindical, iniciado por mulheres insatisfeitas com a não sindicalização no STR e as poucas que eram sindicalizadas não tinham seus direitos e benefícios reconhecidos. A lacuna deixada por essa insatisfação resultou na formação de uma mobilização que destituiu o presidente do Sindicato Rural, na época por meio de eleições legais, do seu posto ocupado havia quase 20 anos, desde a fundação da entidade, criada em novembro de 1972, de acordo com o livro de registro dos associados. A ata de fundação não foi encontrada.

De acordo com a documentação e entrevistas concedidas, esse foi um movimento importante, pois se colocou como o pontapé inicial para a formação de grupos de oposição sindical em outras cidades circunvizinhas, a exemplo de Cubati, que também conseguiu destituir o presidente que havia muito anos ocupado o cargo.

Em Nova Palmeira, a chapa opositora venceu as eleições no STR em 6 de setembro de 1989. O novo presidente, Antônio Pereira Dantas, afinal, ainda era a voz masculina predominante, deu início ao processo de garantia e asseguramento dos benefícios às mulheres já filiadas e à sindicalização das demais. Luisa Marques dos Santos, Dona Mocinha e Maria de Lourdes Ferreira, filiadas em 5 de março de 1989, ainda durante o enfrentamento com o presidente do STR na época, passaram, a partir de setembro do mesmo ano, a ter seus direitos reconhecidos, sendo aposentadas enquanto agricultoras anos depois.

Nesse percurso de luta e formação sindical, surge em janeiro de 1990 o Centro de Educação Popular, na cidade de Nova Palmeira, uma organização não governamental sem fins lucrativos, que passou a dar apoio a essas mobilizações, servindo como suporte fundamental na dinâmica e associativismos nas regiões, uma vez que oferecia assistências com locomoção, alimentação, palestras com pessoas capacitadas, a exemplo de advogados, assistentes jurídicos e políticos. Apoios que fortaleceram os movimentos de oposição sindical. Em 25 de 
julho, desse mesmo ano, a ONG promoveu o Encontro em Comemoração pelo Dia do Trabalhador.

Os Encontros de Oposição Sindical passaram a ser mais constantes com o apoio desse centro. A exemplo do que aconteceu na cidade de Cubati, em 6 de janeiro de 1991, em vista de estarem marcadas as eleições para o STR no dia 20 do referido mês com o apoio do CENEP, da Área Pastoral da cidade, do vereador Babá, filiado ao PT do município de Nova Floresta em 1988, todos esses já envolvidos no chamado Polo Sindical da Borborema, criado nas duas regiões para apoiar as mobilizações sindicais. A chapa opositora ganha força entre os associados, dando início a uma ampla e organizada campanha eleitoral, contando com o apoio efetivo de algumas comunidades rurais, como o Cacimbão, Bela Vista e Capoeira.

Entre os nomes envolvidos nessa campanha estavam o de Maria José da Silva, Albanira Cordeiro de Araújo, Antônio Pereira Dantas (presidente eleito no STR de Nova Palmeira), Luzinete Barros, Maria de Lourdes Gomes - Nega Lourdes - (diretora do CENEP), Marilene Ribeiro, Josefa Maria dos Santos, Rosa Maria dos Santos. Mais uma vez, a figura feminina lança sua participação ativa nos movimentos, dando peculiaridade a um processo que culturalmente deveria ser regido pela força masculina, já que as instituições e a própria sociedade continuam marcadamente impregnada por uma cultura machista, onde o papel da mulher se centra apenas no campo do privado, no lar e afazeres domésticos.

De acordo com o relatório escrito em forma de poesia, datado de 6 de março de 1991, sobre o evento de posse da nova diretora eleita no STR de Cubati, no dia 20 de fevereiro, estiveram presentes nesse ato Antônio Barbosa, representante da CUT Paraíba, além dos presidentes dos STRs das cidade de Nova Floresta, Barra de Santa Rosa e Nova Palmeira.

Os encontros e articulações sindicais não pararam por aí. Ainda segundo os documentos analisados, as reuniões ocorreram ao longo dos anos de 1990 nas duas regiões, a partir de assistências técnicas, assessorias jurídicas, em comunidades rurais, como Bela Vista, cidade de Cubati, sítio Umbuzeiro, município de Pedra Lavrada, por exemplo. Nesses encontros, havia leituras religiosas, cantorias, músicas, apresentação de mamulengos realizadas pelo Grupo de Fantoche Mandacaru, do Cenep. A partir de ma linguagem simples, os espetáculos desse grupo se direcionavam a partir de temáticas ligadas às causas sociais da época, ao mundo do trabalho, estratégias e práticas desenvolvidas para dar corpo a uma consciência crítica e questionadora por parte dos trabalhadores.

A fé, ligada à arte e atrelada ao olhar sensível e dedicado das mulheres, fez das experiências religiosas, artísticas, educativas e sindicais nas regiões do Seridó e Curimataú 
paraibanos terrenos propícios à atuação e transformação social por meio de uma mentalidade questionadora, capaz de mudar os rumos da organização sociopolítica na Paraíba.

\section{Notas}

${ }^{1}$ Segundo Eduardo Paiva (2006), a fonte iconográfica contribui no sentido de melhorar nossa compreensão sobre o objeto estudado. São imagens construídas e por isso podem ser manipuladas, mas associadas a outros registros de um determinado momento nos servem de certidões visuais. São plenas de representações do vivido no tempo e no espaço. Ao utilizarmos esta fonte, precisamos reinterpretá-la, criticá-la sem tomá-la como verdade, pois é lacunar, silenciosa e impregnada de intencionalidades.

${ }^{2}$ Além da fotografia, analisamos produções artísticas paródias, versos escritos por mulheres, bem como relatórios de atividades do Centro de Educação Popular (Cenep), bem como documentos pessoas, tais como anotações, poesias, livros. Esse conjunto de material somado as entrevistas (fonte oral) realizadas, constituem nossos objetos de verificação.

${ }^{3}$ As informações foram extraídas do Relatório de Atividades do CENEP (Nova Palmeira-PB, 10 de março de 1991), bem como das poesias e cantos produzidos para o evento.

4 "Medo da morte: esperança de vida: A história das Ligas Camponesas a Paraíba", dissertação de Maria do Socorro Rangel (2000), sobre as Ligas Camponesas na Paraíba, trazendo enquanto sujeitos de análise a participação de Elisabeth Texeira e Margarida Maria Alves nos movimentos. A tese de Ana Paula Romão, "Paraíba, mulher-macho: (dessa)fios da história (Paraíba, século XX)", (2010), sobre a construção da imagem feminina paraíba, que nos proporcionando refletir sobre os espaços e discursos tecidos sobre a mulher no Estado paraibano.

${ }_{5}$ Maria de Lourdes Gomes de Lima (Nega Lourdes). Professora aposentada e coordenadora geral do Centro de Educação Popular. Entrevista concedida à autora, em 20 de maio de 2014.

${ }^{6}$ A partir de meados da década de 1990 surge no Brasil o chamado "O Grito dos Excluídos", um conjunto de manifestações populares que aconteciam durante as festividades da semana da pátria, com o objetivo de dar visibilidade às insatisfações sociais demandadas das camadas excluídas, denunciando as injustiças sociais vivenciadas pela maioria da população, propondo caminhos para uma sociedade mais justa e igualitária. Essas mobilizações foram iniciadas pela Igreja Católica, ganhando adeptos ao longo do tempo não só Brasil, como na América Latina de forma geral. Muitos grupos adentraram aos movimentos que aconteciam em cada região, levantando suas bandeiras de luta contra as diferentes formas de exclusão e a garantia de participação na sociedade, existindo até hoje no Brasil. Nessa perspectiva e conexão com o contexto social, a passeata das mulheres de Nova Palmeira também tinha por objetivo denunciar os problemas ali existentes.

${ }^{7}$ A cidade de Nova Palmeira fica localizada na microrregião do Seridó paraibano. Sua população é de aproximadamente 5.000 hab., distribuída em uma área de $310,352 \mathrm{~km}^{2}$.

${ }^{8}$ Microrregiões localizadas entre as mesorregiões da Borborema e Agreste paraibanos.

${ }^{9}$ De acordo com Motta (2009), cultura política seria um “conjunto de valores, tradições, práticas e representações políticas partilhadas por determinado grupo humano, que expressa uma identidade coletiva e fornece leituras comuns do passado" (p. 21). A importância dessa concepção se deu pela dinamização da forma de se pensar questões que envolvem cultura, poder e sociedade, possibilitando a construção de novas pesquisas e produções historiográficas, a exemplo dessa dissertação.

${ }^{10}$ A ideia para o projeto, aprovado pelo Programa de Pós-Graduação em História da Universidade Federal da Paraíba em 2014, surgiu a partir de pesquisas iniciadas no final de 2013 para o trabalho de conclusão de curso, que tinha por intenção estudar a atuação social feminina na cidade de Nova Palmeira-PB. O trabalho intitulado (Re)construindo sujeitos,(re)telhando espaços: experiências e práticas de mulheres na cidade de Nova Palmeira-PB (1985-1995) foi defendido e aprovado em 30 de julho de 2014. Dele extraíamos o tema e ampliamos as discussões que nortearam a narrativa dessa dissertação.

${ }^{11}$ De acordo com Nunes (1998/1999), o sindicalismo cutista surge a partir do período chamado de "Novo sindicalismo no Brasil”, que surge em meados da década de 1970, período em que os sindicatos brasileiros não tinham mais nenhuma representatividade. As campanhas iniciadas pelo Sindicato dos Metalúrgicos do ABC paulista fortaleceram as manifestações operárias, impulsionando uma alavancada da classe trabalhadora. Blocos de sindicalistas autônomos e independentes entraram em conflito com o Ministério do Trabalho, gerando tensão e o início de várias greves. Várias conferências de trabalhadores foram organizadas para unificar os vários sindicatos, inclusive os chamados "pelegos", criando em 1982 a Central Única dos Trabalhadores.

${ }^{12}$ Em nível nacional, durante o período do "milagre econômico" (1968-1973), segundo Gohn (2012), visualizase um contexto de forte repressão pela Ditadura Militar, em que os maiores investimentos destinavam-se aos 
grandes empresários e multinacionais que se instalavam no Brasil a partir do acelerado avanço do capitalismo, ficando para as massas populares um violento arrocho, em na maioria das vezes não podiam se manifestar publicamente, pois não havia uma vida político-sindical, apesar de haver empregos, levando a população pobre há uma forte crise econômica.

${ }^{13}$ Sobre o processo de emancipação de municípios nos anos de 1990, ver a dissertação de Josineide da Silva Bezerra, O território como um triunfo: Um estudo sobre a criação de municípios na Paraíba (Anos de 1990), 2006.

${ }^{14}$ Sobre as lutas operárias em Rio Tinto, ver: VALE, Eltern Campina. O sindicato têxtil da cidade-fábrica Rio Tinto: espaço de poder e de disputas políticas (1959-1964). In: CAVALCANTE NETO; GUEDES, Paulo H. M. de Q.; SANTOS NETO, Martinho G. dos (Orgs.). Cultura e poder político: historiografia, imaginário social e representações da política na Paraíba republicana. João Pessoa: Universitária/UFPB, 2012, p. 293-321.

${ }^{15}$ Sobre as Ligas Camponesas na Paraíba, ver. BENEVIDES, Cezar. Camponeses em Marcha. Rio de Janeiro: Paz e Terra, 1985.

${ }^{16}$ Para Michel de Certeau (2008) as "maneiras de fazer" estão ligadas ao consumo, visto como atos astuciosos, que acontecem de forma dispersa, "silenciosa e quase invisível, pois não se faz notar com produtos próprios, mas nas maneiras de empregar os produtos impostos por uma ordem econômica dominante" (p. 39). Essas "maneiras de fazer" formam "mil práticas" pelas quais os "usuários se reapropriam do espaço organizado pelas técnicas de produção sociocultural" (p. 41) e estabelecem outras formas de consumir o que possuem e o que sabem, tecendo no cotidiano práticas particulares.

${ }^{17}$ De acordo com o relatório de atividades, este foi um evento organizado pela ONG Centro de Educação Popular, reunindo tanto as mulheres engajadas nas lutas sociais, quanto as mães das crianças assistidas pela entidade, tendo por objetivo discutir os problemas da sociedade e as formas de como seria possível atuar para minimizar com as fragilidades encontradas.

${ }^{18}$ Fotografias extraídas em blogs; atas de reunião de Câmara Municipal e do STR; relatórios de atividades, de encontros e de seminários, projetos, correspondências, ofícios, abaixo-assinados, produções artísticas (poemas, músicas, paródias, contos, versos) encontrados nos acervos documentais das duas ONGs.

${ }^{19}$ Luisa Marques dos Santos (Dona Mocinha). Professora e agricultora aposentada. Entrevista concedida à autora, em 20 de dezembro de 2013..

${ }^{20}$ Luisa Marques dos Santos (Dona Mocinha).

${ }^{21}$ Margarida Maria Alves foi camponesa, líder de trabalhadores rurais e presidente do Sindicato Rural de Alagoa Grande. Faleceu em 12 de agosto de 1983, "vítima de uma emboscada patrocinada por usineiros e latifundiários do Brejo paraibano.” (FERREIRA, 2010. p. 21).

${ }^{22}$ Ler mais em Susel Oliveira da Rosa, Mulheres versus ditadura, latifúndio e misoginia na Paraíba, 2015.

${ }^{23}$ Os Encontros Zonais são eventos, reuniões, promovidas pela Igreja Católica em parceria com os beneficiários dos Sindicatos Rurais, delimitados por um número " $x$ " de paróquias, em sua maioria, sendo cidades vizinhas, com o objetivo de discutir tanto questões religiosas como políticas.

${ }^{24}$ Entende-se por estratégia a ação realizada a partir de um lugar próprio, já estabelecido que, segundo Michel de Certeau (2008), seria algo um "cálculo (ou a manipulação) das relações de forças que se torna possível a partir do momento em que o sujeito de querer e poder (uma empresa, um exército, uma cidade, uma instituição científica) pode ser isolado" (p. 99), com objetivos já moldados antes mesmo de serem postos em prática. Estratégia tem lugar, hora e alvos marcados, ela impõe e demarca, limita e determina.

\section{Referências Bibliográficas}

ABREU E LIMA, Maria do Socorro de. Construindo o Sindicalismo Rural: lutas, partidos, projetos.2. ed. Recife: Editora Universitária da UFPE, 2012.

BARROS, José d'Assunção. "História social e retorno do político". In: SCHURSTER, Karl; SILVA, Giselda Brito; MATOS, Júlia Silveira. Campos da política: discursos e práticas. São Paulo: LP-Books, 2012, pp. 10-47.

CARVALHO, José Murilo. Cidadania no Brasil: o longo caminho. - $19^{\mathrm{a}}$ ed. - Rio de Janeiro: Civilização Brasileira, 2015.

CATÃO, Francisco A.C. O que é teologia da libertação. São Paulo : Nova Cultural : Brasiliense, 1986. 
CERTEAU, Michel de. A invenção do cotidiano: 1. Artes de fazer.15. ed. Tradução de Ephraim Ferreira Alves. Petrópolis, RJ : Vozes, 2008.

CHAUÍ, Marilena. NOGUEIRA, Marco Aurélio. O pensamento político e a redemocratização do Brasil. Lua Nova, São Paulo, 71 : 173-228, 2007.

GOHN, Maria da Glória. O protagonismo da sociedade civil: Movimentos sociais, ONGs e redes solidárias. $2^{\text {a }}$ ed. São Paulo: Cortez, 2008.

KINZO, MariaD'Alva G. A democratização brasileira: um balanço do processo político desde a transição. São Paulo em Perspectiva (versão online). Vol.15, nº.4. Oct./Dec. 2001.

NUNES, Paulo Giovani Antonino. O surgimento de uma nova força social: o sindicalismo cutista. Revista Saeculum, no 4/5 - jan./dez. 1998-1999, pp. 287-308.

. "Estado versus sociedade civil: o processo de transição para a democracia na Paraíba (1975-1979)". Prima Facie. Revista do Programa de PósGraduação em Ciências Jurídicas da UFPB. Jan./jun, 2009. pp 57-84.

SKIDMORE, Thomas E. "A lenta via brasileira para a democratização: 1974-1985". In: STEPAN, Alfred (org.). Democratizando o Brasil ; tradução Ana Luíza Pinheiro ... [et al.]. Rio de Janeiro: Paz e Terra, 1988.

.p. 27-82.

STEPAN, Alfred (org.). Democratizando o Brasil ; tradução Ana Luíza Pinheiro ... [et al.]. Rio de Janeiro: Paz e Terra, 1988.

RÉMOND, René. “Uma história presente”. In RÉMOND, René. Por uma História Política. Tradução Dora Rocha. 2 ed. - Rio de Janeiro: Editora FGV, 2003, pp. 13-36. 